\title{
Exploratory study of the implications of research on the use of smart connected devices for prevention: a scoping review
}

\author{
Audrey Petit ${ }^{1,2^{*}}$ and Linda Cambon ${ }^{1}$
}

\begin{abstract}
Background: Smart devices and mobile applications are now an integral part of all aspects of everyday life. They are particularly numerous in the field of health, contributing to the movement called ehealth. What is the potential role of these devices as prevention supports? The purpose of this article is to provide an exploratory analysis of the use, efficacy and contribution to conventional prevention strategies.

Methods: To address this issue, we conducted a scoping-review on the basis of 105 publications from the fields of medicine and human sciences.

Results: Three dimensions of the use of smart devices in the field of health were identified: 1/a quantification tool allowing the users to measure their activities; 2/a tool of self-positioning in the community; 3/an interface between the medical world and the population, modifying the hierarchy of knowledge. However, few published studies have investigated the determinants of the efficacy of these devices and their impact on individual behaviours and professional health practices.

Conclusion: Based on the hypothesis of possible integration of these devices in prevention policies, it would be interesting to investigate two research issues: how and under what psycho-socio-environmental conditions can smart devices contribute to the adoption of positive health behaviours? To what degree does the use of smart devices modify the health care professional-patient relationship? Finding answers to these questions could help to define the real place of these devices in prevention strategies by determining their complementarity with respect to other prevention strategies, and the conditions of their efficacy on behaviours and inequalities.
\end{abstract}

Keywords: Smart devices, ehealth, Quantified self, Prevention, Health care relationship

\section{Background}

Smart devices and/or communicating mobile devices $[1,2]$ are internet-connected devices that provide the user with information and an interaction with the environment, specifically linked to a system of identification, sensing and transmission of data (outside temperature, heart rate, etc.) to an application present on an interface (for example, a smartphone) [3]. A

\footnotetext{
* Correspondence: audrey.petit@ehesp.fr

${ }^{1}$ Chaire de recherche en prévention des cancers, UMR6051, CRAPE, EHESP,

Rennes, France

${ }^{2}$ EHESP, 20 Avenue George Sand, 93210 Saint-Denis, France
}

considerable number of these devices and applications, for both the general public and various business sectors, have been released onto the market over recent years [4] and are now an integral part of all aspects of everyday life. For example, in 2013, there were about 9 billion smart devices in the world, i.e. 1.25 smart devices per person [5].

A large proportion of these innovations concern the field of health. These devices, ranging from internet-connected tablet containers to connected wristbands or heart rate monitors and medical alert necklaces for the elderly, are an integral part of the 
"ehealth" movement [6-8] that was initiated at the end of the 1990s. This movement is defined as the use of emerging mobile communications in public health [5, 9-12] designed to change health behaviours and health care. It has been defined as an ally of medicine and biomedical research [13]. About 100,000 applications are now available in the health sector, $70 \%$ of which are related to the well-being segment, concerning almost 5 million people in France [14]. The development of these devices in the health care sector, governed in France by Article L.6316 of the French public health code, is also intensive and diversified: rating scale for chemotherapy sessions and associated adverse effects, textual interpretation of arterial blood gases, management of diabetic patients by a web-based telemonitoring platform [15], teleradiology-based management of neuroradiology emergencies [16], telemedicine applied to muscle rehabilitation [17], telemonitoring in patients with heart failure [18], etc.

Consequently, in the field of health, also marked by increasing life expectancy, an increasing number of chronic diseases and the growth of outpatient management $[19,20]$, these devices will inevitably occupy an increasingly important place alongside conventional curative and preventive health policies and management. However, few data are available, especially in the field of prevention. What is the real value of these devices as a support for prevention behaviours [21, 22]? What questions are currently raised in the literature concerning their use, their efficacy or their contribution to conventional strategies. This article is designed to address these various issues based on a review of the literature.

\section{Method}

In order to address these issues, we conducted a scoping review [23], which can be defined as "exploratory projects that systematically map the literature available on a topic, identifying key concepts, theories, sources of evidence and gaps in the research. They are often preliminary to full syntheses, undertaken when feasibility is a concern - either because the potentially relevant literature is thought to be especially vast and diverse.... or there is a suspicion that not enough literature exists" [24]. We applied the PRISMA guidelines [25] (relevant items: eligibility criteria, information sources, search, study selection).

We performed a literature search using the following key words: prevention OR education AND ehealth OR m-health OR health education AND coaching OR prevention on the Web of Science database. This database was selected because it is a multidisciplinary database that includes the best scientific journals, including in the field of human sciences. We searched for all original and methodological articles indexed between 2000 and 1st December 2015, in English or in French, and selected relevant articles on the basis of their abstracts according to the following criteria: articles concerning the use of smart devices and/or health applications, articles in the field of prevention (in the health system and in other settings), articles concerning modalities of use and/or impact on users, articles on general public interventions. Articles on the curative use of smart devices were excluded. The articles identified were selected by double reading using Covidence software [26]. Certain articles not meeting our selection criteria and not initially selected, but cited in selected articles and likely to be interesting to assess the scope of the subject, were then identified and were added to the selection (doctorate theses, dissertations, didactic articles, methodological articles, scientific articles including human sciences but not in the field of prevention).

We then analysed the selected articles, on the basis of the complete text, according to two questions: What are the objectives of using smart devices in prevention? What questions are raised by the use of smart devices in relation to the conventional prevention strategy? Finally, several other articles, listed in the references of the selected articles, were also progressively included in the analysis, especially human science articles or articles on ehealth, but not concerning the field of prevention.

\section{Results}

Of the 388 articles selected by the search algorithm, 44 were selected on the basis of the inclusion criteria. Excluded articles were mainly excluded because they concerned information technology techniques or curative use (especially telemedicine). Another 61 articles were added to this first selection. A total of 105 publications were finally included in the analysis (see Table 2 in the Appendix) (Fig. 1).

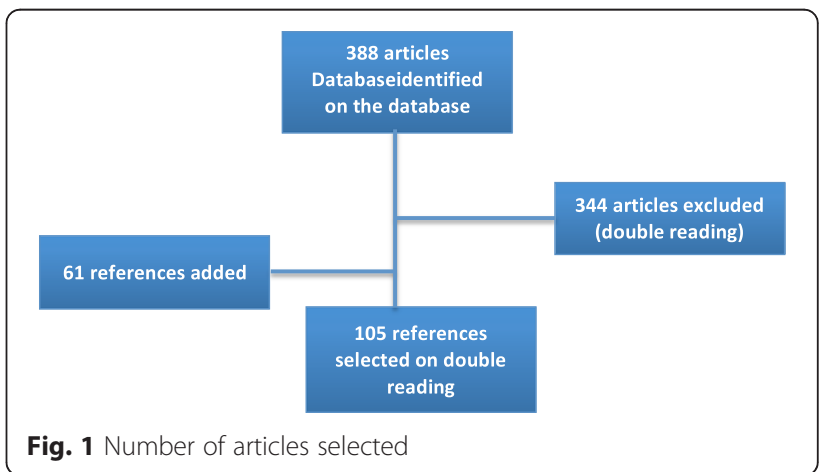


Table 1 List of articles by field of analysis

\begin{tabular}{|c|c|c|c|c|}
\hline & \multicolumn{3}{|c|}{$\begin{array}{l}\text { Purposes of smart device use } \\
\text { (87 references) }\end{array}$} & \multirow[t]{2}{*}{$\begin{array}{l}\text { Modification of prevention } \\
\text { strategies }\end{array}$} \\
\hline & Quantified-self & Socialisation & $\begin{array}{l}\text { Doctor-patient } \\
\text { relationship }\end{array}$ & \\
\hline & (24 references) & (10 references) & (52 references) & (23 references) \\
\hline \multirow[t]{11}{*}{ Article No. } & $1 ; 2 ; 7 ; 8$ & 5 & & \\
\hline & 10 & & $13 ; 14 ; 15 ; 16 ; 17 ; 18 ; 19$ & 14 \\
\hline & $27 ; 28 ; 29 ;$ & & $20 ; 22 ; 28$ & \\
\hline & $\begin{array}{l}30 ; 31 ; 32 ; 33 ; 34 ; 35 ; 36 ; \\
37 ; 38 ; 39\end{array}$ & $32 ; 35 ; 37 ; 39 ;$ & & \\
\hline & 44 & $40 ; 41 ; 42 ; 43 ; 46$ & $45 ; 46 ; 47 ; 48 ; 49 ;$ & 46 \\
\hline & & & $\begin{array}{l}50 ; 52 ; 53 ; 54 ; 55 ; 56 ; 57 \\
58 ; 59\end{array}$ & $52 ; 53$ \\
\hline & & & $\begin{array}{l}60 ; 61 ; 62 ; 63 ; 64 ; 65 ; 66 ; \\
67 ; 68 ; 69\end{array}$ & \\
\hline & & & $\begin{array}{l}\text { 70; 71; 72; 73; 74; 75; 76; } \\
77 ; 78 ; 79\end{array}$ & 72 \\
\hline & $88 ; 89$ & & $80 ; 81 ; 82 ; 83 ; 84 ; 85 ; 86 ; 87$ & $88 ; 89$ \\
\hline & $90 ; 91 ; 92$ & & & $\begin{array}{l}90 ; 91 ; 92 ; 93 ; 94 ; 95 ; 96 ; \\
97 ; 98 ; 99\end{array}$ \\
\hline & & & & 100; 101; 102; 103; 104; 105 \\
\hline
\end{tabular}

The articles were analysed and classified according to two questions. In the first question concerning the purpose of using a smart device, three dimensions were identified: for the purposes of quantification, for the purposes of socialization, for modification of the doctorpatient relationship. This classification is presented in Table 1 below.

\section{Purposes of smart device use}

Three dimensions of the use of smart devices in prevention were identified.

\section{Quantified self devices: objective monitoring of health and health behaviours}

The first dimension considered in the literature concerns quantification of health-related activities or constants [27, 28], corresponding to the sociotechnological "quantified self" movement, also called self-quantifying, self-surveillance, or self-tracking, developed in the United States at the initiative of two Wired magazine journalists, Gary Wolf and Kevin Kelly. This movement has grown considerably over the last 10 years, with the publication of a number of books devoted to its philosophy, quantified self guides $[7,29,30]$ and the creation of a quantified self collective [30]. This movement promotes selfknowledge based on figures provided by connected body sensors on scales, blood pressure monitors or pedometers that send information to a smartphone (m.health [31]). One of the aims of this movement is to quantify all activities or all subjects [32] by means of algorithms [33], even subjective variables such as pain or mood [28].

More specifically, especially in the field of prevention, these devices are designed to collect, measure and compare various biological, physical, behavioural and environmental parameters concerning lifestyle activities such as sleeping, eating and physical exercise, in order to improve well-being and maintain or improve the subject's state of health [34], but also to measure the subject's consumptions (for example smoking, alcohol, calories) or activities (work time, leisure activities, physical exercise, etc.). Some of these data (e.g.: blood pressure, pulse) were conventionally recorded and analysed in the specific setting of the doctor-patient relationship in the context of a specific risk [35]. The quantified self therefore modifies the frontiers between the fields of well-being, health and health care, which now constitute a continuum between normal and pathological rather than a break-point $[10,36]$ The objective for users is to collect data in order to acquire knowledge about themselves and their health in the form of graphic representations reflecting the time-course of selected variables [28]. Self-quantification induces a perception of the body that is modelled in an essentially 
technical relationship determined by quantitative data.

Self-quantification is therefore a way for individuals to objectively visualize their behaviours [37], as part of a strategy of self-knowledge and self-construction [38], although these strategies are not always maintained in the long term [32, 35, 39].

\section{Smart devices as a means of socialization: a source of social valorization}

The second dimension studied in the literature concerns sharing of the data collected and analysed by users of smart devices. Users of these technologies generally belong to internet-connected communities with a double objective of valorization of their efforts and encouraging reassurance according to various configurations. These devices are therefore part of the social interaction economy [40] that highlights the fact that behavioural dynamics are linked to the dynamics of social relationships, whose existence depends on the effects of influence exerted within social groups.

As an example, Lab Orange researchers [32] have defined three types of modalities of use of these measurements. The first consists of surveillance, corresponding to measurement of a risk, in which the concept of threshold plays a central role and is usually defined by external, often medical, norms. This is the case, for example, of body mass index (BMI). This modality does not focus on action, but on selfsurveillance. Consequently, the results of this selfsurveillance can sometimes be a source of anxiety and may therefore not lead to data sharing. According to this modality, advice is then generally shared on social networks according to a logic of mutual aid and support. The second modality concerns what is known as routinization or regularity, which is designed to replace a bad habit by a more favourable health behaviour, for example smoking cessation or adoption of lifestyle and dietary measures. In contrast with the first modality, this modality comprises an action or a change in which the central element is regularity driven by motivation. In this case, publication of the individual's measurements on social networks is designed to arouse encouragement, but the subject may also prefer to avoid other peoples' opinions. Finally, the third modality refers to performance and the various measurements become self-determined objectives. The objective of this modality is to enhance motivation and improve performance. Social networking allows both sharing of experiences as well as competition and the norms derived from the challenge.
In all three cases, these sharing practices constitute tools of technological mediatization and social mediation [37] allowing renewed forms of self-exposure [41] or self-narration [42]. However, networking does not appear to constitute "a standardization of private activities. Although they are driven by the promoters of these tools and the supporters of the quantified self, discussions between users are rare and alignments of practices between the various users does not appear to constitute a dominant expectation" [32]. Moreover, these measuring practices tend to decline with time $[32,35]$, as more than one-third of users stop using their smart device in less than 6 months [5] due to a phenomenon described by the law of attrition [39]. Sharing of measurements recorded by smart devices corresponds to a socialization practice, in which the measurement provides an opportunity to communicate according to new codes $[43,44]$.

\section{Smart devices in the health care relationship: a mediator of participative medicine}

The third dimension identified by this review concerns the medical setting and involves transformations of health care practices related to the emergence and the potential place of these devices in preventive medicine practices $[28,45]$.

The literature on this aspect emphasizes the empowerment potential $[46,47]$ of patients with respect to health care professionals resulting from the use of these devices, allowing them to become active partners of their own health [48]. The use of smart devices in the preventive or curative health care relationship introduces a form of "media medicine" [49] or apomediation [46] meaning remote mediation between the patient and his/her body detached from the doctor, which results in a new doctor/patient relationship articulated around scientific and lay knowledge [19] leading to the emergence of new health care models $[28,50]$. The patient becomes patientexpert and the doctor accompanies the patient in his/her life trajectory [14], by replacing a repair strategy by a lifelong support strategy [51] of an empowered and networking patient [52-54], corresponding to an ascending approach to medicine, which could result in a knowledge competition between health care professionals and their patients [55]. This competition is increasing in parallel with the growth of a large on-line community $[13,28$, 56-61] and information sharing, concerning both disease and healthy lifestyles, which redefine the hierarchy of knowledge [19]. In France, for example, more than one half of the population and $61 \%$ of subjects with a chronic disease search the internet 
for health-related information [50]. Patient communities describe diseases in terms of personal experience $[52,62]$ by means of peer training, information sharing and networking to more effectively manage their health [52, 53]. These patient networks can constitute a new partner in the health care ecosystem [28]. In contrast, few studies have investigated how patients use this information in a context in which the quality of on-line information is not always reliable [57, 63]. Furthermore, sharing of personal information, previously exclusively confided to doctors, raises ethical issues concerning their use and their confidentiality $[64,65]$. Studies examining health care professionals' perception and integration of these devices in preventive medicine practices also highlight the obstacles to their use [66-71] and the need to train both users [72, 73] and health care professionals [74-80] or even the creation of new medical specialties at the interface between information technology and medicine [81, 82]. Finally, these technologies can also impact on relationships between professionals themselves [82] and consequently on the distribution of tasks concerning the patient and his/her care pathway [82-84], leading to more mutualization and less autonomy of professionals.

The use of these devices in the preventive or curative health care relationship is accompanied by new alliances and conflicts between health care professionals and a different sharing of decisions between patients and professionals $[52,55,85-87]$. These changing relations impact on both the nature of the therapeutic alliance, redefining the balance of knowledge between the patient and the health care professional, and the modalities of elaboration of the therapeutic alliance, redefining sharing of skills of the various professionals participating in the patient's care pathway.

These three modalities of use suggest that these devices could possibly contribute to new prevention models.

\section{Smart devices as a support for behaviour change: marker of a new prevention model}

In the light of this review of the literature, these three dimensions of the use of smart devices raise the question of their possible effects on healthrelated behaviour. The underlying hypothesis is that objective demonstration of behaviours (quantified self) may contribute to transformation of the subject's relationship to his/her body and health by adoption and consequently normalization of certain behaviours [88] that could be targeted in prevention policies. Other authors have emphasized the effect of these devices but on the basis of other factors. These devices would therefore contribute to behaviour change [72] and the emergence of a new representation of the body and health by promoting empowerment, which cannot be achieved by the biomedicine model [89]. Empowerment is "an individual's capacity to take decisions when faced with a specific situation or problem, either alone or by group participation, in order to adapt to this situation and take control of their personal life" [14]. In other words, by means of objective measurement of their health and behaviour, individuals would be more able to make more favourable adaptive choices. Several studies [90-92] have corroborated this hypothesis in the clinical practice setting, by showing that the "patient's implication in management of his or her treatment has beneficial effects [...]. It improves treatment adherence in many diseases and doctors are currently trying to develop tools that can enhance this implication" [52]. The efficacy of ehealth, in the broad sense of the term, has therefore been demonstrated in many fields such as overweight and obesity [93, 94], HIV [95-97], cancer [98-100] and diabetes [92, 101]. Nevertheless, few studies have demonstrated the efficacy and use of these smart devices with respect to conventional strategies. The question of their universal accessibility and consequently the social inequalities that can be induced by the use of these devices $[102,103]$, also needs to be investigated, as there is a risk that the digital divide $[53,104]$ may further accentuate the health divide between users with access to this technology and those without access to this technology [46].

The use of these devices as a support for health behaviour changes, and therefore as a specific prevention tool, needs to be further investigated both in terms of the way in which these devices act (empowerment versus normalization), and their efficacy and contribution to the problems of social and regional health inequalities.

\section{Discussion}

Although not as comprehensive as a systematic review of the literature, this scoping review provides a fairly precise overview of the research issues present in the literature concerning the use of smart devices in prevention strategies, either outside of the medical field (health and well-being) or in the context of clinical prevention practices (health and prevention of diseases or their complications). We have limited our research to the field of prevention and we have 
excluded the very abundant literature on curative aspects and have also included publications derived from the fields of human and social sciences. We consequently observed that a large number of articles were excluded and many articles not meeting our inclusion criteria also had to be added $(n=61)$. These screening failures could be explained by two hypotheses. Firstly, our search algorithm was too broad: in particular, the word "coaching" refers to support, essentially therapeutic support, but not necessarily associated with a smart device or an application. The use of this search term selected a large number of irrelevant articles. The second hypothesis concerns the salience of this innovative subject, especially in the so-called grey literature (not referenced in scientific databases) and in fields not related to health.

Three main dimensions were identified. Each dimension situates the smart device in the context of a specific objective and a specific use. The first dimension positions the device as a tool for quantification of activity, allowing users to measure their activities, assess their progress and project themselves towards a target. It consequently constitutes a selfconstruction tool providing an objective measure of self-control, assuming that the self can be defined by these variables. The second dimension concerns selfpositioning in the community. As a vector of collective socialization, the device provides an opportunity to seek advice and encouragements. The third dimension is that of a mediator between an environment considered up until now to be a source of knowledge, the medical environment, and the population. This mediation breaks down the barriers of knowledge, redefining the relationship between patients and health care professionals and between professionals concerning curative or preventive management, which is consequently transformed in terms of its scientific basis and its methods. In view of these elements, smart devices can be considered to be tools that could be integrated into the conventional prevention arsenal, and therefore subject to the same fundamental questions: what is the final objective (empowerment versus normalization)? And what is the impact on social and regional health inequalities [105]?

In reality, these findings highlight a blind spot in the literature: explanation of the mechanisms of efficacy of these devices and their impact on health practices and professional practices, as few studies have investigated the mechanisms mobilized by the use of these devices in favour of health behaviours. In fact, beyond the question of the quality and reliability of the data and algorithms integrated into these devices, their objectives and the scope of their use in prevention need to be precisely defined: What are the psychosocial mechanisms underlying the use of these devices for the purposes of health? What are the objectives of these devices: to monitor, improve performance, accompany behaviour changes, develop empowerment, etc.? In what types of populations are they relevant (age, gender, socioeconomic category, medical history)? In what way do they compensate or complete conventional strategies? What socio-environmental factors potentiate or limit the effects of these devices on behaviour change? The data derived from the literature also fail to provide any details on the absolute efficacy or the efficacy according to social gradient of these devices in the field of prevention nor the conditions of this efficacy.

Finally, very few data are available in the literature to explain the transformations of practices induced by the use of smart devices in the health care relationship and the impact of this transformation on the health system and its capacity to provide an egalitarian response to the population's needs, as it is unclear from this scoping review whether these changes apply to all fields of prevention and health care and all types of patients. How do health care professionals adapt to these new practices? More broadly, how is the health system preparing for this transformation and what changes will be required in the training of health care professionals?

\section{Conclusion}

To conclude, this scoping review identified three different dimensions concerning the use of smart devices in prevention. Based on the hypothesis of integration of these devices into prevention policies, this review emphasizes the importance of investigating two questions that have been poorly studied to date, although they represent a real research challenge in this field: how and under what psycho-socioenvironmental conditions can ehealth smart devices contribute to the adoption of positive health behaviour? To what degree and how does the use of smart devices positively or negatively modify the doctorpatient relationship?

Finding answers to these questions could help to define and confirm the real place of these devices in prevention strategies by clearly demonstrating their added value and complementarity with respect to other prevention strategies, and by defining the conditions of their efficacy on behaviours, especially by taking into account the question of social and regional inequalities of access to health care. 


\section{Appendix}

Table 2 List of articles selected

\begin{tabular}{|c|c|c|c|c|c|c|}
\hline No. & Year & Author & Language & Type & Selection & Criteria \\
\hline 1 & 2013 & Benferhat & French & Doctorate thesis & Addition & $\begin{array}{l}\text { Smart devices } \\
\text { In the health system } \\
\text { Quantified-self }\end{array}$ \\
\hline 2 & 2012 & Swan & English & Original article & Database & $\begin{array}{l}\text { Health applications Non-health setting } \\
\text { Quantified-self }\end{array}$ \\
\hline 3 & 2014 & Lendrevie & French & Book & Addition & $\begin{array}{l}\text { Health applications } \\
\text { Non-health setting }\end{array}$ \\
\hline 4 & 2014 & Bellanger-Trely & French & Vade Mecum & Addition & $\begin{array}{l}\text { Smart devices } \\
\text { Health applications } \\
\text { In the health system and other settings }\end{array}$ \\
\hline 5 & 2015 & IREPS Bretagne & French & Grey literature & Addition & $\begin{array}{l}\text { Smart devices } \\
\text { Health applications } \\
\text { Modalities of use } \\
\text { In the health system and other settings }\end{array}$ \\
\hline 6 & 2011 & Dupagne & French & Original article & Database & $\begin{array}{l}\text { Health applications } \\
\text { In the health system }\end{array}$ \\
\hline 7 & 2014 & Robin & French & Book & Addition & $\begin{array}{l}\text { Health applications } \\
\text { Modalities of use } \\
\text { In the health system }\end{array}$ \\
\hline 8 & 2012 & Wiederhold & English & Original article & Database & $\begin{array}{l}\text { Smart devices } \\
\text { Modalities of use } \\
\text { In the health system }\end{array}$ \\
\hline 9 & 2014 & CATEL & French & Guidelines & Addition & $\begin{array}{l}\text { Health applications } \\
\text { In the health system }\end{array}$ \\
\hline 10 & 2015 & CNOM & French & Guidelines & Addition & $\begin{array}{l}\text { Health applications } \\
\text { Modalities of use } \\
\text { In the health system }\end{array}$ \\
\hline 11 & 2001 & Eysenbach & English & Original article & Database & $\begin{array}{l}\text { Health applications } \\
\text { Modalities of use } \\
\text { In the health system }\end{array}$ \\
\hline 12 & 2011 & Garel & French & Book & Addition & $\begin{array}{l}\text { Health applications } \\
\text { Modalities of use } \\
\text { In the health system }\end{array}$ \\
\hline 13 & 2008 & Eysenbach & English & Original article & Database & $\begin{array}{l}\text { Health applications } \\
\text { Impact on users } \\
\text { In the health system }\end{array}$ \\
\hline 14 & 2014 & Salmon & French & Original article & Database & $\begin{array}{l}\text { Impact on users Prevention strategies } \\
\text { In the health system and other settings }\end{array}$ \\
\hline 15 & 2013 & Benhamou & French & Original article & Database & $\begin{array}{l}\text { Health applications } \\
\text { Impact on users } \\
\text { In the health system }\end{array}$ \\
\hline 16 & 2008 & Hazebroucq & French & Original article & Database & $\begin{array}{l}\text { Health applications } \\
\text { Impact on users } \\
\text { In the health system }\end{array}$ \\
\hline 17 & 2008 & Avraam & English & Original article & Database & $\begin{array}{l}\text { Health applications } \\
\text { Impact on users } \\
\text { In the health system }\end{array}$ \\
\hline 18 & 2012 & Bignolas & French & Original article & Addition & $\begin{array}{l}\text { Health applications } \\
\text { Impact on users } \\
\text { In the health system }\end{array}$ \\
\hline 19 & 2014 & Dubey & French & Original article & Database & $\begin{array}{l}\text { Health applications } \\
\text { Impact on users } \\
\text { In the health system }\end{array}$ \\
\hline
\end{tabular}


Table $\mathbf{2}$ List of articles selected (Continued)

\begin{tabular}{|c|c|c|c|c|c|c|}
\hline 20 & 2006 & Giustini & English & Original article & Database & $\begin{array}{l}\text { Health applications } \\
\text { Impact on users } \\
\text { In the health system }\end{array}$ \\
\hline 21 & 2014 & Merloz & French & Original article & Database & $\begin{array}{l}\text { Health applications } \\
\text { In the health system }\end{array}$ \\
\hline 22 & 2014 & Vial & French & Original article & Addition & $\begin{array}{l}\text { Health applications } \\
\text { Impact on users } \\
\text { In the health system }\end{array}$ \\
\hline 23 & 2010 & Levac & English & Methodological article & Database & - \\
\hline 24 & 2010 & IRSC & French & Grey literature & Addition & - \\
\hline 25 & 2008 & Mother & English & Methodological article & Addition & - \\
\hline 26 & 2014 & Babineau & English & Methodological article & Addition & - \\
\hline 27 & 2014 & Beauchet & English & Original article & Database & $\begin{array}{l}\text { Smart devices } \\
\text { Modalities of use } \\
\text { In the health system }\end{array}$ \\
\hline 28 & 2009 & Swan & English & Original article & Database & $\begin{array}{l}\text { Smart devices } \\
\text { Health applications } \\
\text { Modalities of use } \\
\text { Impact on users } \\
\text { In the health system and other settings }\end{array}$ \\
\hline 29 & 2008 & Cotteret & French & Book & Addition & $\begin{array}{l}\text { Smart devices } \\
\text { Modalities of use }\end{array}$ \\
\hline 30 & 2012 & Gadenne & French & Book & Addition & $\begin{array}{l}\text { Smart devices } \\
\text { Modalities of use Non-health setting }\end{array}$ \\
\hline 31 & 2015 & Ahmadvand & English & Original article & Database & $\begin{array}{l}\text { Smart devices } \\
\text { Modalities of use } \\
\text { In the health system and other settings }\end{array}$ \\
\hline 32 & 2013 & Pharabond & French & Original article & Database & $\begin{array}{l}\text { Smart devices } \\
\text { Modalities of use } \\
\text { Non-health setting }\end{array}$ \\
\hline 33 & 1990 & Laguna & English & Original article & Addition & $\begin{array}{l}\text { Smart devices } \\
\text { Modalities of use } \\
\text { In the health system }\end{array}$ \\
\hline 34 & 2008 & Reiter & English & Original article & Database & $\begin{array}{l}\text { Smart devices } \\
\text { Modalities of use } \\
\text { Non-health setting }\end{array}$ \\
\hline 35 & 2014 & CNIL & French & Grey literature & Addition & $\begin{array}{l}\text { Smart devices } \\
\text { Modalities of use } \\
\text { Non-health setting }\end{array}$ \\
\hline 36 & 1966 & Canguilhem & French & Book & Addition & Modalities of use \\
\hline 37 & 2013 & Arruabarrena & French & Original article & Addition & $\begin{array}{l}\text { Smart devices } \\
\text { Modalities of use } \\
\text { Non-health setting }\end{array}$ \\
\hline 38 & 2012 & Mondoux & French & Original article & Addition & Health applications Modalities of use \\
\hline 39 & 2005 & Eysenbach & English & & Database & $\begin{array}{l}\text { Modalities of use } \\
\text { Non-health setting }\end{array}$ \\
\hline 40 & 1993 & Manski & English & Original article & Addition & Modalities of use \\
\hline 41 & 2010 & Granjon & French & Original article & Addition & Modalities of use \\
\hline 42 & 2006 & Cardon & French & Original article & Addition & Modalities of use \\
\hline 43 & 2009 & Aguiton & English & Original article & Addition & Modalities of use \\
\hline 44 & 2014 & Caldwell & English & Original article & Database & Modalities of use \\
\hline 45 & 2013 & Delmotte & French & Original article & Addition & $\begin{array}{l}\text { Health applications Impact on users } \\
\text { In the health system }\end{array}$ \\
\hline 46 & 2011 & Casilli & French & Original article & Addition & Modalities of use Prevention strategies \\
\hline
\end{tabular}


Table $\mathbf{2}$ List of articles selected (Continued)

\begin{tabular}{|c|c|c|c|c|c|c|}
\hline 47 & 2008 & Van Uden-Kraan & English & Original article & Addition & $\begin{array}{l}\text { Impact on users } \\
\text { In the health system and other settings }\end{array}$ \\
\hline 48 & 1999 & Charles & English & Original article & Addition & $\begin{array}{l}\text { Impact on users } \\
\text { In the health system }\end{array}$ \\
\hline 49 & 2015 & Vallancien & French & Book & Addition & $\begin{array}{l}\text { Impact on users } \\
\text { In the health system }\end{array}$ \\
\hline 50 & 2015 & Wernette & French & Original article & Addition & Impact on users \\
\hline 51 & 2014 & Caniart & French & Original article & Addition & $\begin{array}{l}\text { Health applications } \\
\text { In the health system and other settings }\end{array}$ \\
\hline 52 & 2010 & Jouet & French & Review & Addition & Impact on users Prevention strategies \\
\hline 53 & 2015 & Brouard & French & Original article & Database & Impact on users Prevention strategies \\
\hline 54 & 2008 & Frost & English & Original article & Addition & $\begin{array}{l}\text { Impact on users } \\
\text { In the health system and other settings }\end{array}$ \\
\hline 55 & 2011 & Laubie & French & Original article & Database & $\begin{array}{l}\text { Impact on users } \\
\text { In the health system and other settings }\end{array}$ \\
\hline 56 & 2009 & Akrich & French & Original article & Addition & $\begin{array}{l}\text { Impact on users } \\
\text { Non-health settings }\end{array}$ \\
\hline 57 & 2008 & Mayoh & English & Original article & Database & $\begin{array}{l}\text { Impact on users } \\
\text { In the health system and other settings }\end{array}$ \\
\hline 58 & 2015 & Valdez & English & Original article & Addition & $\begin{array}{l}\text { Impact on users } \\
\text { In the health system and other settings }\end{array}$ \\
\hline 59 & 2015 & Magnezi & English & Original article & Addition & $\begin{array}{l}\text { Impact on users } \\
\text { In the health system and other settings }\end{array}$ \\
\hline 60 & 2014 & Magnezi & English & Original article & Addition & $\begin{array}{l}\text { Impact on users } \\
\text { In the health system and other settings }\end{array}$ \\
\hline 61 & 2013 & Medina & English & Original article & Addition & $\begin{array}{l}\text { Impact on users } \\
\text { In the health system and other settings }\end{array}$ \\
\hline 62 & 2014 & Delory-Momberger & French & Original article & Addition & $\begin{array}{l}\text { Impact on users } \\
\text { In the health system and other settings }\end{array}$ \\
\hline 63 & 2008 & Mitchell & English & Original article & Database & $\begin{array}{l}\text { Impact on users } \\
\text { In the health system }\end{array}$ \\
\hline 64 & 2014 & Béranger & French & Original article & Database & $\begin{array}{l}\text { Impact on users } \\
\text { In the health system }\end{array}$ \\
\hline 65 & 2009 & Lucas & French & Original article & Database & $\begin{array}{l}\text { Impact on users } \\
\text { In the health system }\end{array}$ \\
\hline 66 & 2012 & Gagnon & English & Methodological article & Database & $\begin{array}{l}\text { Impact on users } \\
\text { In the health system }\end{array}$ \\
\hline 67 & 2012 & Gund & English & Original article & Database & $\begin{array}{l}\text { Impact on users } \\
\text { In the health system }\end{array}$ \\
\hline 68 & 2008 & Ward & English & Methodological article & Database & $\begin{array}{l}\text { Impact on users } \\
\text { In the health system }\end{array}$ \\
\hline 69 & 2012 & Dünnebeil & English & Original article & Database & $\begin{array}{l}\text { Impact on users } \\
\text { In the health system }\end{array}$ \\
\hline 70 & 2009 & Eley & English & Original article & Database & $\begin{array}{l}\text { Impact on users } \\
\text { In the health system }\end{array}$ \\
\hline 71 & 2005 & Richards & English & Original article & Database & $\begin{array}{l}\text { Impact on users } \\
\text { In the health system }\end{array}$ \\
\hline 72 & 2010 & Sandrin-Berthon & French & Book & Addition & $\begin{array}{l}\text { Prevention strategies } \\
\text { Impact on users } \\
\text { In the health system }\end{array}$ \\
\hline 73 & 2005 & Eymard & French & Original article & Addition & $\begin{array}{l}\text { Impact on users } \\
\text { In the health system }\end{array}$ \\
\hline 74 & 2002 & Gros & French & Rapport & Addition & $\begin{array}{l}\text { Impact on users } \\
\text { In the health system }\end{array}$ \\
\hline
\end{tabular}


Table $\mathbf{2}$ List of articles selected (Continued)

\begin{tabular}{|c|c|c|c|c|c|c|}
\hline 75 & 2013 & Dattakumar & English & Original article & Addition & $\begin{array}{l}\text { Impact on users } \\
\text { In the health system }\end{array}$ \\
\hline 76 & 2013 & Lapao & English & Original article & Addition & $\begin{array}{l}\text { Impact on users } \\
\text { In the health system }\end{array}$ \\
\hline 77 & 2012 & Bygholm & English & Original article & Addition & $\begin{array}{l}\text { Impact on users } \\
\text { In the health system }\end{array}$ \\
\hline 78 & 2011 & Stellefson & English & Methodological article & Addition & $\begin{array}{l}\text { Impact on users } \\
\text { In the health system }\end{array}$ \\
\hline 79 & 2009 & Clark & English & Original article & Addition & $\begin{array}{l}\text { Impact on users } \\
\text { In the health system }\end{array}$ \\
\hline 80 & 2008 & Zvarova & English & Original article & Addition & $\begin{array}{l}\text { Impact on users } \\
\text { In the health system }\end{array}$ \\
\hline 81 & 2003 & Moulin & French & Original article & Addition & $\begin{array}{l}\text { Impact on users } \\
\text { In the health system }\end{array}$ \\
\hline 82 & 2013 & Mathieu-Fritz & French & Original article & Addition & $\begin{array}{l}\text { Impact on users } \\
\text { In the health system }\end{array}$ \\
\hline 83 & 2011 & Esterle & French & Original article & Addition & $\begin{array}{l}\text { Impact on users } \\
\text { In the health system }\end{array}$ \\
\hline 84 & 1992 & Strauss & French & Book & Addition & Impact on users \\
\hline 85 & 2012 & Andrieu & French & Book & Addition & $\begin{array}{l}\text { Impact on users } \\
\text { In the health system }\end{array}$ \\
\hline 86 & 2009 & Silber & French & Original article & Addition & $\begin{array}{l}\text { Impact on users } \\
\text { In the health system and other settings }\end{array}$ \\
\hline 87 & 2009 & Silber & French & Original article & Addition & $\begin{array}{l}\text { Impact on users } \\
\text { In the health system }\end{array}$ \\
\hline 88 & 2014 & Martin & French & Dissertation & Addition & $\begin{array}{l}\text { Health applications Impact on users } \\
\text { Prevention strategies } \\
\text { Non-health setting }\end{array}$ \\
\hline 89 & 2015 & Thornquist & English & Original article & Database & $\begin{array}{l}\text { Health applications Impact on users Prevention strategies } \\
\text { Non-health setting }\end{array}$ \\
\hline 90 & 2014 & Shull & English & Methodological article & Database & $\begin{array}{l}\text { Health applications Impact on users } \\
\text { Prevention strategies } \\
\text { In the health system and other settings }\end{array}$ \\
\hline 91 & 2015 & Van den Bulck & English & Original article & Database & $\begin{array}{l}\text { Health applications Impact on users } \\
\text { Prevention strategies } \\
\text { Non-health setting }\end{array}$ \\
\hline 92 & 2015 & Goyal & English & Original article & Database & $\begin{array}{l}\text { Health applications Impact on users } \\
\text { Prevention strategies } \\
\text { Non-health setting }\end{array}$ \\
\hline 93 & 2015 & Hutchesson & English & Methodological article & Database & $\begin{array}{l}\text { Health applications Prevention strategies } \\
\text { In the health system }\end{array}$ \\
\hline 94 & 2013 & Tate & English & Original article & Database & $\begin{array}{l}\text { Health applications Prevention strategies } \\
\text { In the health system }\end{array}$ \\
\hline 95 & 2014 & Odeny & English & Original article & Database & $\begin{array}{l}\text { Health applications Prevention strategies } \\
\text { In the health system }\end{array}$ \\
\hline 96 & 2015 & Muessig & English & Original article & Addition & $\begin{array}{l}\text { Health applications Prevention strategies } \\
\text { In the health system }\end{array}$ \\
\hline 97 & 2012 & Noar & English & Original article & Database & $\begin{array}{l}\text { Health applications Prevention strategies } \\
\text { In the health system }\end{array}$ \\
\hline 98 & 2013 & Sanchez & English & Methodological article & Database & $\begin{array}{l}\text { Health applications Prevention strategies } \\
\text { In the health system }\end{array}$ \\
\hline 99 & 2013 & Elliot & English & Original article & Database & $\begin{array}{l}\text { Health applications Prevention strategies } \\
\text { In the health system }\end{array}$ \\
\hline 100 & 2015 & Davis & English & Original article & Database & $\begin{array}{l}\text { Health applications Prevention strategies } \\
\text { In the health system }\end{array}$ \\
\hline
\end{tabular}


Table $\mathbf{2}$ List of articles selected (Continued)

\begin{tabular}{|c|c|c|c|c|c|c|}
\hline 101 & 2012 & Pacaud & English & Original article & Addition & $\begin{array}{l}\text { Health applications Prevention strategies } \\
\text { In the health system }\end{array}$ \\
\hline 102 & 2014 & Steinberg & English & Original article & Database & $\begin{array}{l}\text { Health applications Prevention strategies } \\
\text { In the health system }\end{array}$ \\
\hline 103 & 2009 & Atkinson & English & Original article & Addition & $\begin{array}{l}\text { Health applications Prevention strategies } \\
\text { In the health system }\end{array}$ \\
\hline 104 & 2011 & Granjon & French & Original article & Addition & $\begin{array}{l}\text { Prevention strategies } \\
\text { In the health system and other settings }\end{array}$ \\
\hline 105 & 2015 & Zhang & English & Original article & Addition & $\begin{array}{l}\text { Prevention strategies } \\
\text { In the health system }\end{array}$ \\
\hline
\end{tabular}

\section{Acknowledgements}

There are no acknowledgements.

\section{Funding}

No funding.

\section{Availability of data and materials}

Not applicable.

\section{Competing interests}

The authors declare that they have no competing interests.

\section{Authors' contributions}

AP made substantial contributions to conception and design, acquisition of data, analysis and interpretation of data; drafting and critical review of the manuscript for important intellectual content; she agrees to be accountable for all aspects of the work by ensuring that questions related to the accuracy or integrity of any part of the work are appropriately investigated and resolved. LC made substantial contributions to conception and design, acquisition of data, analysis and interpretation of data; drafting and critical review of the manuscript for important intellectual content; she agrees to be accountable for all aspects of the work by ensuring that questions related to the accuracy or integrity of any part of the work are appropriately investigated and resolved and to give final approval of the version to be published. Both authors read and approved the final manuscript.

\section{Consent for publication}

Not applicable.

\section{Ethical approval and consent to participate}

Not applicable.

\section{Received: 31 January 2016 Accepted: 24 June 2016}

\section{Published online: 11 July 2016}

\section{References}

1. Benferhat D. Conception d'un système de communication tolérant la connectivité intermittente pour capteurs mobiles biométriques. Application à la supervision médicale de l'activité cardiaque de marathoniens [Thèse de doctorat en informatique]. Université de Bretagne Sud; 2013.

2. Swan M. Sensor mania! The internet of things, wearable computing, objective metrics, and the quantified self 2.0. J Sens Actuator Netw. 2012; 1(3):217-53

3. Lendrevie J, Lévy J. Mercator 11e édition - Tout le marketing à l'ère numérique. Avec e-book. 11th ed. Paris: Dunod; 2014. p. 1040

4. Bellanger-Trely M-V. Vade-Mecum des objets connectés. Réalités, tendances et futur proche. APSSIS. APSSIS; 2014.

5. IREPS Bretagne. Santé connectée...que la magie opère! Horiz Plur. 2015;(28)

6. Dupagne D. E-santé. Communications. 2011; $n^{\circ}$ 88(1):57-65.

7. Robin J-Y. L'urgence numérique. Faire de la France un leader de l'e-santé. L'Harmattan. 2014. p. 214

8. Wiederhold BK. Self-tracking: better medicine through pattern recognition. Cyberpsychol Behav Soc Netw. 2012:15(5):235-6.

9. CATEL. Préconisations e-santé 2014. Catel; 2014. p. 69
10. Conseil national de l'Ordre des médecins. Santé connectée. De la e-santé à la santé connectée. Le livre blanc du Conseil National de l'Ordre des Médecins. 2015

11. Eysenbach G. What is e-health? J Med Internet Res [Internet]. 2001;3(2):E20 [cited 2015 Oct 9].

12. Garel P. Systèmes d'information en santé et TIC. E-Santé Etat Lieux Eur. 2011:539:78-80

13. Eysenbach G. Medecine 2.0 : social networking, collaboration, participation, apomediation and openness. J Med Internet Res. 2008;10(3):e22.

14. Salmon FD, Tallec LL. La e-santé: de nouveaux usages pour les technologies individuelles en santé publique. Ann Mines - Réal Ind. 2014;2014(4):70-5.

15. Benhamou P-Y, Muller M, Lablanche S, Debaty I. La télémédecine au service de la prise en charge des patients diabétiques; développements actuels et conditions du succès. Eur Res Telemed Rech Eur En Télémédecine. 2013; 2(1):23-8.

16. Hazebroucq V, Fery-Lemmonier E. Apports de la téléradiologie dans la prise en charge des urgences neuroradiologiques./data/revues/ 01509861/00310004/334/[Internet]. 2008 [cited 2015 Oct 22].

17. Avraam $M$, Horodinca $M$, Letier $P$, Preumont A. Portable smart wrist rehabilitation device driven by rotational MR-fluid brake actuator for telemedecine applications. In: IEEE/RSJ International Conference on Intelligent Robots and Systems, 2008 IROS 2008. 2008. p. 1441-6.

18. Bignolas G. Filieris: un modèle organisationnel des soins. Gerontol Soc. 2012; HS 1(5):137-48

19. Dubey G. Les nouvelles technologies en autonomie et santé : un déplacement des frontières de la connaissance. Ann Mines - Réal Ind. 2014; 4:82-8.

20. Giustini D. How Web 2.0 is changing medicine. BMJ. 2006;333(7582):1283-4

21. Merloz P. À quoi servent les nouvelles technologies en médecine et en chirurgie? Ann Mines - Réal Ind. 2014;2014(4):12-6.

22. Vial A. Les technologies s'opposent-elles à la médecine humaniste ? une (fausse) question vieille comme le monde. Ann Mines - Réal Ind. 2014:4:6-11.

23. Levac D, Colquhoun H, O'Brien KK. Scoping studies: advancing the methodology. Implement Sci IS. 2010:5:69.

24. Instituts de recherche en santé du Canada. Guide sur la synthèse des connaissances - IRSC [Internet]. 2010 [cited 2015 Nov 12].

25. Mother L, Liberati A, Tetzlaff J, Altman D, The PRISMA Group. Preferred reporting items for systematic reviews meta-analyses: the PRISMA Statement. PLoS Med. 2009;6(7):e1000097.

26. Babineau J. Product review: covidence (Systematic Review Software). J Can Health Libr Assoc J Assoc Bibl Santé Can. 2014;35(2):68-71.

27. Beauchet O, Launay CP, Merjagnan C, Kabeshova A, Annweiler C. Quantified self and comprehensive geriatric assessment: older adults are able to evaluate their own health and functional status. Plos One. 2014;9(6):e100636.

28. Swan M. Emerging patient-driven health care models: an examination of health social networks, consumer personalized medicine and quantified self-tracking. Int J Environ Res Public Health. 2009:6(2):492-525.

29. Cotteret M-A. Mesurez vous de la métrologie à l'autonomie. Ovadia. 2008. 130p.

30. Gadenne E, Devesa F, Wolf M. Guide pratique du Quantified Self. Mieux gérer sa vie, sa santé, sa productivité. Limoges: Editions Fyp; 2012. p. 224.

31. Ahmadvand A, Whittaker R, Lim MSC. Placing prevention in the pockets: the role of mHealth. In: Adibi $S$, editor. Preventive medical services. Boca Raton: Crc Press-Taylor \& Francis Group; 2015. 
32. Pharabond A-S, Nikolski V, Granjon F. La mise en chiffres de soi: une approche compréhensive des mesures personnelles. Réseaux. 2013;177(1): 97-129

33. Laguna $P$, Thakor NV, Caminal $P$, Jané $R$, Yoon H-R, de Luna AB, et al. New algorithm for QT interval analysis in 24-hour Holter ECG: performance and applications. Med Biol Eng Comput. 1990;28(1):67-73.

34. Reiter H, Naujokat E, Pinter R, Devot S. TakeCare: A Home-based Sensor System for the Management of Cardiovascular Risk Factors Primary prevention by monitoring vital body signs, analysing the data and closing the loop by feedback, coaching, and motivation. New York: leee; 2008.

35. CNIL. Le corps, nouvel objet connecté. Cahiers Innovation et Prospective $n^{\circ}$ 2. 2014.

36. Canguilhem G. Le normal et le pathologique. Paris: Presses universitaires de France; 1966.

37. Arruabarrena $B$, Quettier P. Des rituels de l'automesure numérique à la fabrique autopoïétique de soi. Cah Numér. 2013:9(3):41-62.

38. Mondoux A. À propos du social dans les médias sociaux. Termin Technol Inf Cult Société. 2012:111:69-79.

39. Eysenbach G. The law of attrition. J Med Internet Res. 2005;7(1):e11.

40. Manski CF. Identification of endogenous social effects: the reflection problem. Rev Econ Stud. 1993;60(3):531-42.

41. Granjon F, Denouël J. Exposition de soi et reconnaissance de singularités subjectives sur les sites de réseaux sociaux. Sociologie. 2010;1(1):25-43.

42. Cardon D, Delaunay-Téterel H. La production de soi comme technique relationnelle. Réseaux. 2006;138(4):15-71.

43. Aguiton C, Cardon D, Castelain A, Fremaux P, Girard H, Granjon F, et al. Does Showing Off Help to Make Friends? Experimenting a Sociological Game on Self-Exhibition and Social Networks. In: Third International AAAI Conference on Weblogs and Social Media [Internet]. 2009 [cited 2015 Oct 9].

44. Caldwell T. The quantified self: a threat to enterprise security? Comput Fraud Secur. 2014;11:16-20

45. Delmotte $\mathrm{H}$. De la e-santé à la santé connectée: accompagner la transformation de notre modèle de santé. Hegel. 2015;2(5):123-6.

46. Casilli A. Usages numériques en santé : conflictualité épistémique et sociale dans les communautés de patients en ligne. In: n Claude-Marie LaedleinGreilsammer (dir) Internet: des promesses pour la santé? Actes des Journée 2011 Euro Cos Humanisme et Santé [Internet]. Paris: Editions de santé; 2011. p. 181-91 [cited 2015 Oct 22].

47. van Uden-Kraan CF, Drossaert CHC, Taal E, Shaw BR, Seydel ER, van de Laar MAFJ. Empowering processes and outcomes of participation in online support groups for patients with breast cancer, arthritis, or fibromyalgia. Qual Health Res. 2008;18(3):405-17.

48. Charles C, Whelan T, Gafni A. What do we mean by partnership in making decisions about treatment? BMJ. 1999;319(7212):780-2.

49. Vallancien G. La médecine sans médecin ? Le numérique au service du malade. Paris: Gallimard; 2015.

50. Wernette F. L'e-santé, un colosse aux pieds d'argile. Actual Pharm. 2015; 54(544):23-30

51. Caniard E. Avant-propos. Ann Mines - Réal Ind. 2014;4:3-5.

52. Jouet E, Flora L, Las Vergnas O. Construction et reconnaissance des savoirs expérentiels. Note de synthèse. Pratique de formationanalyses. Université Paris 7 (France) Centre de recherche éducation et formation; 2010

53. Brouard B. Les nouvelles technologies de la communication au service de la santé. Actual Pharm. 2015;54(544):18-22.

54. Frost $J$ H, Massagli MP. Social uses of personal health information within PatientsLikeMe, an online patient community: what can happen when patients have access to one another's data. J Med Internet Res. 2008; 10(3):e15.

55. Laubie R. Le patient connecté ou les métamorphoses de la santé. Expans Manag Rev. 2011;143(4):24-31.

56. Akrich M, Méadel C. Les échanges entre patients sur l'Internet. Presse Med. 2009;38(10):1484-90

57. Mayoh J. Will the development of Web 2.0 technology result in a preference for quantity over quality? In Toronto, Canada; 2008 [cited 2015 Oct 23]

58. Valdez RS, Brennan PF. Exploring patients' health information communication practices with social network members as a foundation for consumer health IT design. Int J Med Inf. 2015;84(5):363-74.
59. Magnezi R, Grosberg D, Novikov I, Ziv A, Shani M, Freedman LS Characteristics of patients seeking health information online via social health networks versus general Internet sites: a comparative study. Inform Health Soc Care. 2015:40(2):125-38.

60. Magnezi R, Bergman YS, Grosberg D. Online activity and participation in treatment affects the perceived efficacy of social health networks among patients with chronic illness. J Med Internet Res. 2014;16(1):e12.

61. Medina EL, Loques Filho O, Mesquita CT. Health social networks as online life support groups for patients with cardiovascular diseases. Arq Bras Cardiol. 2013;101(2):E39-44.

62. Delory-Momberger C, Tourette-Turgis C. Vivre avec la maladie. Sujet Dans Cité. 2014;5(2):33-8.

63. Mitchell S. Women Wading Through the Web: providing women with the tools to evaluate online health information. Med 20 Conf [Internet]. 2008 Nov 6 [cited 2015 Oct 23].

64. Béranger J, Bouadi R. Approche éthico-juridique de l'usage des données médicales à caractère personnel. Cah Numér. 2014;10(2):93-123.

65. Lucas J. Diffusion des informations médicales à l'épreuve des usagers de I'Internet: quelques réflexions d'éthique et de déontologie. Presse Med. 2009;38(10):1451-5.

66. Gagnon M-P, Desmartis M, Labrecque M, Car J, Pagliari C, Pluye P, et al. Systematic review of factors influencing the adoption of information and communication technologies by healthcare professionals. J Med Syst. 2012; 36(1):241-77.

67. Gund A, Lindecrantz K, Schaufelberger M, Patel H, Arne B. Attitudes among healthcare professionals towards ICT and home follow-up in chronic heart failure care. BMC Med Inform Decis Mak. 2012;12:138.

68. Ward R, Stevens C, Brentnall P, Briddon J. The attitudes of health care staff to information technology: a comprehensive review of the research literature. Health Inf Libr J. 2008;25(2):81-97.

69. Dünnebeil S, Sunyaev A, Blohm I, Leimeister JM, Krcmar H. Determinants of physicians' technology acceptance for e-health in ambulatory care. Int J Med Inf. 2012;81(11):746-60.

70. Eley R, Fallon T, Soar J, Buikstra E, Hegney D. Barriers to use of information and computer technology by Australia's nurses: a national survey. J Clin Nurs. 2009;18(8):1151-8.

71. Richards H, King G, Reid M, Selvaraj S, McNicol I, Brebner E, et al. Remote working: survey of attitudes to eHealth of doctors and nurses in rural general practices in the United Kingdom. Fam Pract. 2005;22(1):2-7.

72. Sandrin-Berthon B. L'éducation du patient au secours de la médecine. PUF. 2010. 198 p. (Education et formation)

73. Eymard C, Gatto F, Dodo J, Plat F. Exister avec le diabète de type 1 : l'éducation à la santé face aux savoirs expérientiel des patients. Diabètes Educ. 2005;2(15):8-16.

74. Gros J. Santé et nouvelles technologies de l'information. Note d'léna. 2002 avril No: 98.

75. Dattakumar A, Gray K, Maeder A, Butler-Henderson K. Ehealth Education for Future Clinical Health Professionals: An Integrated Analysis of Australian Expectations and Challenges. In: Lehmann CU, Ammenwerth E, Nohr C, editors. Medinfo 2013: Proceedings of the 14th World Congress on Medical and Health Informatics, Pts 1 and 2. Amsterdam: los Press; 2013. p. 954.

76. Lapao LV, Gregorio J, Ferreira T, Cavaco A, Lovis C, Russo G, et al. eHealth Services for Enhanced Pharmaceutical care Provision: From Counseling to Patient Education. 2013, leee 2nd Int Conf Serious Games Appl Health Segah. 2013.

77. Bygholm A, Gunther J, Bertelsen P, Nohr C. eHealth Education of Professionals in the Baltic Sea Area. In: Mantas J, Andersen SK, Mazzolen MC, Blobel B, Quaglini S, Moen A, editors. Quality of Life Through Quality of Information. Amsterdam: los Press; 2012. p. 934-8.

78. Stellefson M, Hanik B, Chaney B, Chaney D, Tennant B, Chavarria EA. eHealth literacy among college students: a systematic review with implications for eHealth education. J Med Internet Res. 2011;13(4):e102.

79. Clark J, Baker B, Baker D. Getting eHealth into Basic Nursing Education: Report of the RCN Information in Nursing Project. In: Saranto K, Brennan PF, Park HA, Tallberg M, Ensio A, editors. Connecting Health and Humans. Amsterdam: I O S Press; 2009. p. 534-9.

80. Zvarova J. Education in Biomedical Informatics and eHealth. In: Blobel B, Pharow P, Nerlich M, editors. Ehealth: combining health telematics, telemedicine, biomedical engineering and bioinformatics to the edge: global experts summit textbook. Amsterdam: Ios Press; 2008. p. 27-32. 
81. Moulin T, Retel O, Chavot D. Impacts des nouvelles technologies informatiques et de communication (NTIC) sur l'organisation hospitalière et la prise en charge des patients: Réseau d'Aide au Diagnostic et aux Soins des Urgences Neurologiques (RAIDS-UN). Santé Publique. 2003;Vol. 15(HS): 191-200.

82. Mathieu-Fritz A, Esterle L. Les transformations des pratiques professionnelles lors des téléconsultations médicales. Coopération interprofessionnelle et délégation des tâches. Rev Fr Sociol. 2013;54(2):303-29.

83. Esterle L, Mathieu-Fritz A, Espinoza P. L'impact des consultations à distance sur les pratiques médicales : vers un nouveau métier de médecin? Rev Fr Aff Soc. 2011;2-3:63-79.

84. Strauss AL. La trame de la négociation: sociologie qualitative et interactionnisme. Paris: L'Harmattan; 1992.

85. Andrieu B. L'autosanté : Vers une médecine réflexive. Armand Colin; 2012. p. 256.

86. Silber D. Médecine 2.0; les enjeux de la médecine participative. Presse Med. 2009;38(10):1456-62

87. Silber D. L'Internet et le partage de la décision médicale entre patients et professionnels de santé. Presse Med. 2009;38(10):1491-3.

88. Martin B. La quantification de soi dans les réseaux socionumériques [Mémoire de maîtrise en communication]. [Montréal]: Université du Québac: 2014.

89. Thornquist $\mathrm{E}$, Kirkengen AL. The quantified self: closing the gap between general knowledge and particular case? J Eval Clin Pract. 2015; 21(3):398-403

90. Shull P, Jirattigalachote W, Hunt MA, Cutkosky MR, Delp SL. Quantified self and human movement : a review on the clinical impact of wearable sensing and feedback for gait analysis and intervention. Gait Posture. 2014 40:11-9.

91. Van den Bulck J. Sleep apps and the quantified self : blessing or curse? J Sleep Res. 2015;2(24):121-3.

92. Goyal S, Morita P, Lewis GF, Yu C, Seto E, Cafazzo JA. The systematic design of a behavioural mobile health application for the self-management of type 2 diabetes. Can J Diabetes. 2016;40(1):95-104.

93. Hutchesson MJ, Rollo ME, Krukowski R, Ells L, Harvey J, Morgan PJ, et al. eHealth interventions for the prevention and treatment of overweight and obesity in adults: a systematic review with meta-analysis. Obes Rev. 2015; 16(5):376-92.

94. Tate EB, Spruijt-Metz D, O'Reilly G, Jordan-Marsh M, Gotsis M, Pentz MA, et al. mHealth approaches to child obesity prevention: successes, unique challenges, and next directions. Transl Behav Med. 2013;3(4): 406-15.

95. Odeny TA, Newman M, Bukusi EA, McClelland RS, Cohen CR, Camlin CS. Developing content for a mHealth intervention to promote postpartum retention in prevention of Mother-To-Child HIV transmission programs and early infant diagnosis of HIV: a qualitative study. Plos One. 2014;9(9): e106383.

96. Muessig KE, Bien CH, Wei C, Lo EJ, Yang M, Tucker JD, et al. A mixedmethods study on the acceptability of using eHealth for HIV prevention and sexual health care among men who have sex with men in China. J Med Internet Res. 2015;17(4):e100.

97. Noar SM, Willoughby JF. eHealth interventions for HIV prevention. Aids Care-Psychol Socio-Med Asp AidsHiv. 2012;24(8):945-52.

98. Sanchez MA, Rabin BA, Gaglio B, Henton M, Elzarrad MK, Purcell P, et al. A systematic review of eHealth cancer prevention and control interventions: new technology, same methods and designs? Transl Behav Med. 2013;3(4): 392-401.

99. Elliot DL, Lindemulder SJ, Goldberg L, Stadler DD, Smith J. Health promotion for adolescent childhood leukemia survivors: building on prevention science and ehealth. Pediatr Blood Cancer. 2013;60(6): 905-10.

100. Davis SW, Oakley-Girvan I. mHealth education applications along the cancer continuum. J Cancer Educ Off J Am Assoc Cancer Educ. 2015;30(2):388-94.

101. Pacaud D, Kelley H, Downey AM, Chiasson M. Successful delivery of diabetes self-care education and follow-up through eHealth media. Can J Diabetes. 2012;36(5):257-62

102. Steinberg DM, Levine EL, Lane I, Askew S, Foley PB, Puleo E, et al. Adherence to self-monitoring via interactive voice response technology in an eHealth intervention targeting weight gain prevention among black women: randomized controlled trial. J Med Internet Res. 2014;16(4):105-16.
103. Atkinson NL, Saperstein SL, Desmond SM, Gold RS, Billing AS, Tian J. Rural eHealth nutrition education for limited-income families: an iterative and user-centered design approach. J Med Internet Res. 2009; 11(2):e21.

104. Granjon F. Fracture numérique. Communications. 2011;88(1):67-74.

105. Zhang $X, Y u$ P, Yan J, Spil ITAM. Using diffusion of innovation theory to understand the factors impacting patient acceptance and use of consumer e-health innovations: a case study in a primary care clinic. BMC Health Serv Res. 2015;15(1):71.

\section{Submit your next manuscript to BioMed Central and we will help you at every step:}

- We accept pre-submission inquiries

- Our selector tool helps you to find the most relevant journal

- We provide round the clock customer support

- Convenient online submission

- Thorough peer review

- Inclusion in PubMed and all major indexing services

- Maximum visibility for your research

Submit your manuscript at www.biomedcentral.com/submit
Biomed Central 